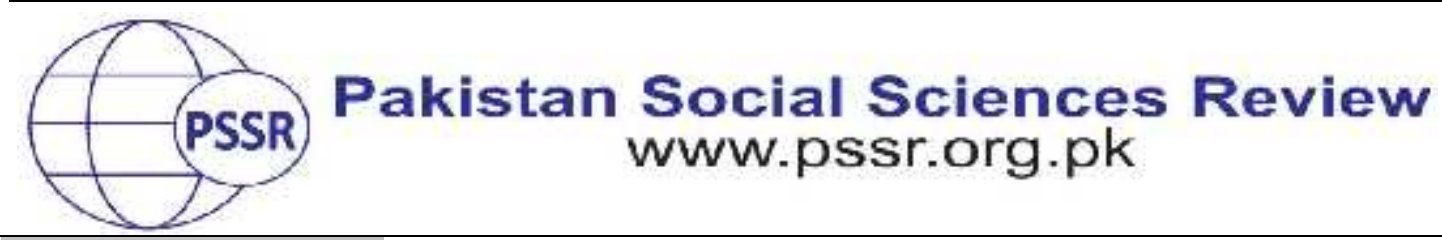

RESEARCH PAPER

\title{
Social Stratification in a Punjab Village in New Millennium
}

\author{
Dr. Imran Khan ${ }^{1}$ Dr Karim Haider Syed ${ }^{2}$
}

1. Post-docs Scholar, Department of Geography, University of the Punjab Lahore, Punjab, Pakistan

2. Post-docs Scholar, Department of Geography, University of the Punjab Lahore, Punjab, Pakistan

\begin{tabular}{|c|c|}
\hline ATEN IINT & (5) \\
\hline $\begin{array}{l}\text { d: } \\
2021 \\
\text { d: } \\
0,2021 \\
4,2021\end{array}$ & $\begin{array}{l}\text { This paper is very important hist } \\
\text { society in Pakistan. There have } \\
\text { studies on rural societies in last sev } \\
\text { that contain first hand direct info }\end{array}$ \\
\hline $\begin{array}{l}\text { Keywords: } \\
\text { Changes, } \\
\text { Nauthen, } \\
\text { Punjab, } \\
\text { Rural, } \\
\text { Settlement, } \\
\text { Social, }\end{array}$ & $\begin{array}{l}\text { her for the und } \\
\text { ortant. This pa } \\
\text { re and interac }\end{array}$ \\
\hline i & $\begin{array}{l}\text { lages. Regional studies have a single purf } \\
\text { eck on assumptions made about a broade } \\
\text { vancing our understanding of social proc }\end{array}$ \\
\hline
\end{tabular}

\section{Introduction}

In the last figure on population in Pakistan, rural share of population is 62.83 percent (WB, 2020). Its mean the majority population of Pakistan is still living in rural areas, walking out the cities everyone can watch the great ocean of Pakistan's villages. In the Indian subcontinent Pakistan in the $21^{\text {st }}$ century is land of villages. Regionalism has always prevailed, but not in seclusion. For archival purposes, the regional approach is just as valid as the national or universal one. This research work has focused on a micro-study of the village of Nauthen in the Pindi Bhattian tehsil of the Punjab's District Hafizabad. This paper will mostly focus on Punjab. The village Nauthen in tehsil Pindi Bhattian of Punjab's District Hafizabad. The word "Punjab" is a combination of two words from the Persian language 'Punj' which means five and 'Aab' meaning water, that gave the definite connotation to the phrase "the Land 
of five rivers" that is translated in Persian as Punjab. The name of these five rivers are Chenab, Ravi, Beas, Sutlej and Jhelum (Gupta, 1991, p17). Hafizabad district has area of 2367 square kilometer that was formally settled in the era of Mughal Emperor Akbar on the request of Sufi saint Sarmast buried in city Hafizabad, by the advisor of emperor Hafiz Meerak. It became important place during the reign of Akbar as it was raised to status of Mahal (District) as it is mentioned in famous book Ain-eAkbari by advisor of Emperor Akbar (Fazal \& Blochmann, 1997, p. 324) and also mentioned in biography of Tuzgh e Jhangiri when emperor Jahangir when he visited the place (Jahangir, Rogers, \& Beveridge, 1968, p. 113). Punjab remained an important part of Indian social and political order before and after the Mughal rule in India and it is playing an important role in Indian and Pakistani social and political systems. In Pakistan Punjab is largest province in population and majority population of Punjab is still living in the rural areas; i.e. villages. So a study on the rural area of Punjab is very important for better understanding of life in rural Punjab and Pakistan. It is matter of fact the advancement in the agricultural sector of Punjab has special impact on the society of Punjab and changes in the result of modern technology are very important part of social development in rural areas. Rural society of Punjab is passing through a new phase of social and economic changes, so a micro study on the social life of rural Punjab is very important to draw results at macro level (Gamsa, 2017). Nauthen is village with 906 households and 5925 population. The coordinates of Nauthen are as $31^{\circ} 56^{\prime} 16^{\prime \prime} \mathrm{N}$ and $73^{\circ} 31^{\prime} 50^{\prime \prime} \mathrm{E}$. Nauthen is Union Council No. 26 having 4194 votes in total falling in 87th constituency of National Assembly and 71th constituency of Punjab Assembly ("List of polling stations for a constituency of election to the national assembly of the N.A-87 Hafizabad", 2018). Uduo Singh and Natha Singh were two Sikhs of Hunjra tribe who dug two water wells which grew into two villages, Udoka Well and Nautha, now a days Udokey and Nauthen Village. Uduo had a small well in the southwestern side of current settlement of Nauthen that reflect the close relationship of Uduo and Natha as some elders used to say that they were two brothers. When the left the area is not clear but they had left long before the arrival of Randhaira Kharal tribe from Danabad in 1782. A small foot prints of an old settlement were in the southern side of current settlement of Nauthen that currently is under the possession of Nasar Kharal son of Saday Khan. There were ruins of settlement used by the new settlers of Randhiara tribe as ranch for animals and the area still is called Bhattian wala. Some of the elders says Bhatti were Thekeydars (tenants), who used the pace as ranch not as homes (Diwana, 2016) and left the area for some reasons most probably of wars with Ranjit Singh in 1799. Microhistory is a historical genre that concentrates on small units of study, such as an event, particularly in the relationship of micro- and macro-levels of history. There is a lot of debate in the sociological literature over the theory of social class and, more generally, class system. Many theories and frameworks have been used to evaluate classification systems, which refer to the hierarchical organization of groups in a society or community. One of the goals of this research is to see if some of the principles can be applied to data from a Punjabi village. 


\section{Literature Review}

(Servinas, 1950) in her paper under title; social structure of Punjab, added very important work on village studies that was published in The Economic Weekly, researcher was working in Punjab in 1948-49 to collect data and after getting enough she provided very important work on the village life of Punjab. (Ahmad, 1970) in his work social stratification in Punjab has provided with the details of the different changes of castes and causes of these changes. This work also shed light on the social structure of the Punjab and being a micro study this work provided the details of different caste living in the village Jalpana in Punjab in the 1960s. In his work he provided new theories to understand the changes of castes in village society and impact of education and development on the cast system in Punjab.(Singh, 2009), provided very good data on the nature of changes in villages of Indian Punjab after the modernization and introduction of new technologies. His work was also a micro study on the changes in the rural life in Indian Punjab in which he provide some insight on the changes of systems and culture of the Indian Punjab. This paper provide very useful information for this new study.

\section{A Description of Nauthen}

Micro Study is complementary for macro study. Village Nauthen is chosen for micro study of the changes in rural society in Punjab due to modernization. Modernization is term that means transformation from the rural and traditional to urban and modern society. All most all of the villages are passing through this process some with speed and some slowly. For complete overview of changes in the rural society in Punjab, it will be important to introduce the village under study along with the region. Nauthen village is twenty kilometer in south of district headquarter of Hafizabad, only three kilometer in north of Kotsarwar interchange of M-2. It is 106 kilometer in northeast of Lahore the capital of Punjab and 280 kilometer in southwest of Islamabad the federal capital of Pakistan. Looking at the history of Hafizabad, it became tehsil of Gujranwala district in 1849 and district in 1993. Hafizabad district has two tehsil, Hafizabad and Pindi Bhattian. Village Nauthen is in Tehsil Pindi Bhattian and Pindi Bhattian city was founded by Bhatti tribe that served as important castle of Bhatti tribe during Mughal and Sikh era. Nauthen village basically divided into nine different settlements (Bashmula) that had created misconcept about the name of Nauthen that name of the village is derived from $\mathrm{Nu}$ (Nine) and Thehan (Punjabi word used for village) $\mathrm{Nu}$ Thehan means Nine villages. With the passage of time new wells were dug and on the new wells different families settled permanently. Nine Bashmula of Nauthen are Jandwala Khuh, (A well that had a Jand a kind of tree), Roudu Khuh ( A well that was in Roud or Nasheebi (flood Land), Saru Khuh ( A well that was under the possession of people of Saru Patti), Maal wala Khuh ( A well that was used to provide water to Maal Dangar (animals), Chuntra (a high bed of land), Dull Wahab (A small well under the use of family of Mr. Wahab Kharal), Dull Jahana ( A small Well under the use of Family of Mr. Jahana Kharal), Station ( A settlement around the railway station) and Nauthen Pind (Main village Nauthen) (Safdar, 2020). Nauthen is situated in the north-eastern part of the province in the Rechan-Doab, an 
area situated between Chenab and Ravi rivers and area of Sandal Bar that is known for the Jhumar and sammi form of music and dance. The great Mughal Emperor Akbar the great had named the regions; between Beas and Sutlej rivers was named as Bhat or Bahat Julandhar Doab, between Ravi and Beas River was named as Bari Doab, between Chenab and Ravi riverswas named as Rachna Doab, between Jehlum and Chenab rivers was named as Jahat and in some documents as Chaj Doab and between Indus and Jhelum rivers was named as Sind Sagar Doab (Faizi and Balochmann, 2010) ( Doab, 2020). There are four famous bars or Baran; Bar is word of Punjabi language that means an area away from the human settlement, an outer place, a threshold, the area between two rivers is bar if that shaped a natural barrier between two diverse settlements on their bank. The Sandal Bar (the area between the Ravi and Chenab rivers).The great Punjabi folk tales or happened in the Sandal Bar is also famous for the epic love stories like those of Mirza, Saheban and Heer and Ranjha. Sandal Bar also was home to Dulla Bhatti who rebelled against the Mughal emperor Akbar and refused to pay agricultural revenue (Lagaan), (Khan, 2017). The area between the Easter side of Jehlum River and western side of Chenab is called Kirana Bar taking name from the area of Kirana, and after it the area between Sutlej river and Ravi river is called Neeli Bar, the area between the Hakra having dry river bed and Sutlej is called Ganji Bar that is well known for Punjabi freedom fighter Rai Ahmad Khan Kharal (1785-1857), a folk hero, who embrace martyrdom during his fight against the British Raj in 1857. Theses Bars' still have almost the similar culture and dialect or language with minor variations. (Soofi, 2014) Nauthen village in Sandal bar. The village is in the Majha tract, Majha mean middle of the Punjab, so the Majhi dialectic of Punjabi is spoken in Nauthen. Nauthen were part of Sangla or Sakala, the capital city of Punjab when Alexander the great passed through this area, he met with one of the most serious confrontation from the Sakala area in his career of victory. After it, when the Chinese pilgrim Hwen Tsang in 630 passed through this area and mentioned a kingdom with Name, Asarur that turned Khangah Asrur now a days (Mian Ali village near Khangah Dogran), the town of Khangah Dogran was once known as Khangah Masrur Dogar, Mian Ali was once known as Asrur a capital of kingdom that was stretching from Indus to Beas river ("Geography of District Hafizabad", 2020), so it can be said that Nauthen was part of this Kingdom. In the era of Muslim rule it remained part of Hafizabad that was an important place along with Eminabad. During the Mughal rule, there were six Parganas, namely, Hafizabad, Sohdra, Eminabad, Sahomalli, Sheikhupura and Chatha and Sheikhupura. Eminabad and Hafizabad were the principle places in now a days Gujranwala division neither wazirabad nor Gujranwala. (Fazal \& Blochmann, 1997, p. 324) It is very sensible to note that Nauthen would have part of Hafizabad or Sheikhupura. In the late $18^{\text {th }}$ century a Randhaira subtribe of Kharal cast migrated from Syedwala in 1782 to settle in this village. They arrived in Nauthen nearly eight generations back, looking at pedigree of Muhammad Ali Randhiara died in last day of December 2012, from him, Muhammad son of Jalal Khan son of Bahawal son of Sukha son of Nauta son of Daulat son of Muazzam (Mujam) Son of Peer Muhammad son of Qaim son of Jalal (Jalalia). Peer Muhammad who most probably was living in 1782 and arrived with his two other brothers, Chakar and Faqir Muhammad and 
sons, cousins and nephews in Nauthen along with tribes of Hamaon, Saru, Aaqal and Ghulla. They had killed Qamar Singh Nakai in Rupa Mahtarm village near Danaabad and syedwala on the bank of Ravi River in 1780. Qamar Singh was leader of Nakai Misl of Sikhs, he was replaced by Wazir Singh Nakai who killed Rai Amir Kharal of Upaira Kharal clan andthe leader of these Randhaira tribe in revenge of Qamar Singh Nakai alongwith many others in fight and finally forced the Randhaira Kharal tribe to leave the area. Some of them fled to Barkhardar a town near Danaabad and Syedwala that was under the control of rival family of Nakai sardar of Wazir Singh and some marched towards Gurdaspur. But majority of Randhaira Kahral tribe marched toward Chiniot where they sought help of Ghalam Abbas Shah as Shah Family was predecessors of Sheikh Samail or Ismail Shah Bukhari who was Mureed of Qutbe Aalam Khuwaja Noor Muhammad Chisti Maharvi Kharal (Haider \& Khan, 2017). Ghulam Abbas shah taken the Randhira tribe towards Pindi Bhattian and further marched towards Jangla Jagir (Now a days Village in Tehsil Pindi Bhattian). In Jangla Jagir that was under the administration of Sawan Mall, and a tribe of Lodeka Kharal was settled in early $18^{\text {th }}$ century. Ghulam Abbas Shah sought Nauthah Khoh (water well) near Udoka Khoh ( Udoka well) for settlement of Randhaira tribe but roundabout the Nauthah well there was dense forest. People used to say that no one can live at Nauthah well as that was living place of a lion, so the Randhaira Kharal tribe stayed at Udoka Khoh for a time being as it was under the control of Lodeka Kharal tribe. After a short stay they had to leave that place as dispute on the reconstruction of wall of well was arisen and Randhaira Kharal Tribe had to make arrangement for settlement at their own well of Nauthah. (Mulla, 2020) Basically Nautha and Udo were two persons of Hanjra tribe of Sikh religion who dug these two big wells for irrigation and drinking water and some small wells (khohis) one of the Udos Khohi (small well) was in southwest of Nautha's well. On the visit of Ghulam Abbas Shah Randhaira Kharal tribe asked him for prayer of protection against attack of lion, so he put Dheengri (big dry branch of tree) towards the eastern side of Nauthah Khoh (well). For the said reason for the time being people used to name this settlement as Dheengri Gulam shah but later on it became Nauthah Khoh and finally after partition became Nauthen (Dosat, 2020). During the Sikh era and initial years of the British era Nauthen was part of Wazirabad or Shiekhupura District and between 1851-1852, Gujranwala was raised as district headquarter and wazirabad was reduced to tehsil and three new tehsils of Hafizabad, Gujranwala, Ramnagar (currently Rasul Nagar) were created. In the settlement of 1855 Ramnagr lost the status of Tehsil and it was divided between Hafizabad and Wazirabad. Some parts of Sheikhupra were included in Hafizabad and remaining were transferred to newly created Tehsil of Sharqpur. Nauthen remained part of Hafizabad Tehsil till 1893 and after it became part of newly created tehsil Khankah Dogran in October 1893 with area of 873 square kilometer. When Khangah Masrur Dogar became headquarter of newly created tehsil with tehsil office, thana or police station and sub registrar office, Nauthen became part of Khangh Dogran Tehsil of Gujranwala district (District Gazteer Gujranwala, 18931894). Nauthen connected with Hafizabad through railway lined when Hafizabad to Sangla Hill railway line became operational on 1-1-1896 a 31.45 miles long railway line. In 1910 Sheikhupura was created as district that taken Sharkpur Tehsil from 
Lahore district and Khangah Tehsil from Gujranwala. In the process few areas from Khangah Dogran tehsil were cede to Hafizabad tehsil including Nauthen. In 1993 Hafizabad raised to district level and Pindi Bhattian raised as Tehsil and Nauthen became part of Pindi Bhattian Tehsil (Rashid, 1961).

\section{Hypothesis}

Modernization has direct impact on the social structure of the rural society in Punjab as the nature of relations, entertainment and culture in villages is passing through the process of change.

\section{Material and Methods}

This paper needs very special techniques of research methods as large number of data that is used in this research work is collected from the primary sources. The purpose is to examine and describe the classification structure of a Punjabi village, Nauthen, which is indicative of a wide rural area in Punjab in many aspects (Pakistan). The data for this research were gathered from the village over the course of a year's stay from 2012-2020, through observation and interviews with several knowledgeable members of village society. The available data for this work was explained with the descriptive model of research and help is taken from the secondary sources of data in shape of books, website and journals.

\section{Results and Discussion}

\section{Demographic Changes after Partition of India}

The partition of India changed the demography of the Punjab as large number of non-Muslims migrated from west Punjab to Eastern Punjab, huge number of migrants came in West Punjab from East Punjab. Demographic changes were not limited to urban areas as rural areas were also affected from the partition and Nauthen a village in Punjab was also among those areas effected from the partition of India in 1947. Before partition there were few non-Muslim families living in Nauthen and all were mutually exclusive. One was Sundar Khatari having wife Deva or Devaan and three daughters Giani, Rami and Kushliya (not confirm) but no son. The family of Sundar was very rich having, his own small well for drinking water and baths before his house and beautiful horse, he purchased land from Urura son of Salam son of Umar on the name of a Tarar of Rasulpur as Sahokars were ineligible to purchase land in Punjab, his house and land is under the occupation of Rai Mansha son of Ahmad and his well and ranch is under Dulla Mirasi. Second non-Muslim family in Nauthen was family of Kashi or Kanshi Khatri the Gold smith, this family migrated from Vanikey Tarar and settled in Nauthen and was married in Kassoki in Sikh family. He had three sons Amar Singh, Guru Bux Singh, Bansa Singh. They had joint house with Muslim family of Nur Muhammad Kharal son of Murad, as house was designed in such manner that two rooms of Nur was on eastern side and two rooms of Kashi Khatri was on eastern side with common 
courtyard. Amar Singh son of Kashi and Sher Muhammad son of Nur in June 1947 went to Amritsar by train from Nauthen to Sangla and Sangla to Lahore and from Lahore to Amritsar. Kashi was god fearing person and people used to say him Bhagat, after partition for few years his house was intact as he used to visit his house that is under the possession of Sher Muhammad. Budh Singh was an important person as he had a son Hari Singh. Hari Singh was married to Maya and had three Sons Piyara Singh, Kartar Singh and Lal Singh (Lali) and three daughter Shanti, Gyanti and Rami. Lal Singh was born in 1935 but was unmarried in 1947 when partition took place, their residence is under the occupation of Nazir son of Smanda Kharal, his ranch was shared with Jalal son of Bahwal Kharal and he had very good relations with family of Jalal as he used to come and play with baby boy Muhammad the son of Jalal. After partition his ranch came under occupation of Bahawal son of Sukha Kharal and now a days under the use of Khalid Kumhar. Nihal Khatri was another important family, he had two sons Bahadar and Sudagar and were Kumhar. They also work in agricultural fields on labor. Bahadur and Sudagar used to steal the hens from village and eat them after cooking. Their house came under the occupation of a migrant family of Ghulam Ali and Niaz Ali Dhobi. Two shopkeeper families were family of Kaiser Khatri and Ganesha. Kaiser house was occupied by Kabar son of Bahu Kharal, Ganesha house was occupied by Munda son of Shashu Kharal and now a days under the use of his son Zia. Other non-Muslims in Nauthen were Mela Khatri, whose house came under the use of Chachu Zafar Fson of Saddad Kharal, Sardari Khatri was a school teacher in Nauthen and his house came under the use of Liaqat son of Sada Kharal, Gana Ditta a shopkeeper had a son Durshiand Khyrati and a daughter Rami from his wife Lachmi, whose house and shop is under Liaqat son of Sada Kharal, Hira Singh was married to Ram Pyari whose house is under the use of Sadiq son of Raja Kharal. Gobind Singh was a Hakeem and had a small Gurduwara in which there was holy book under the cover of beautiful cover of cloth and there was no idol in the Gurdawara. He married and on his marriage arranged Band, he wanted to serve Halwa to his guests but when the Band reached on the roof of his house they paly band and a dog sitting on the roof jumped in Halwa and wasted, his house is under the use of Ishfaq son of Khan Kharal in Nauthen and some says there was a Mandir in a house near to the current residence of Bhand, and Gobid used live in the house that came under the use of Chappa Bhand. Shero and Mathelo were Sounsi (Low caste in Punjab) used to eat dogs and Niazo Ghadela (low Cast in Punjab) was also from low cast used to live in Jandwala Khuh whereDuri chand or Duni Chand used to live as Jandwala Khuh (well) was a small separate settlement of Nauthen. Duni Chand was very pious person as it is famous that when his dead body wa set on fire, fire did not touch his body and on the request of Muslims he was buried according to Muslims rituals. His house remained the under the use of Deendar family. Another Kahtri was Tuti Khatri living in Chuntra a sub settlement of Nauthen adjacent to sukheki service area on M2. Other known and relevant family of non-Muslim was family of Karam Singh Khatri, who lived in Udoki a village of Lodekey Kharal. He was person of political influence as he took approval of Raliway station of Nautheh (Nauthen), he had a son Bhagwan Singh. When Abdul Malik (Mali) son of Qalandar son of Shahru (Shharyar) killed Shah Muhammad (Shahu) son Gajju (Gajjan) then Karam Singh helped the 
Sharyar family by giving loan to Khan Son Bahal son of Qanda Son of Sharyar, Jahana and Baqar Son of Qalandar and took animals to recover his loan after the end of case. Another important non-Muslim was Uttma Singh, living in Udoki. He had love marriage in Muslim family as he converted to Islam and adopted name of Ahmad Din. He refused to leave his village and live peacefully till his death but had no children. In the weddings Muslim used to send uncooked items as meal to nonMuslims houses as they did not like to eat the meal cocked by Muslims but nonMuslims sent cocked meals as Muslims had no such issues with non-Muslims. After the partition all non-Muslim left the village, and in first step shifted in Camp of Migrants that was established at Kaleki Railway station. All the Non-Muslims left the village peacefully and with the hope that one day they could return back. For years their property remained untouched as Kashi a gold smith used to come his house in Nauthen after partition and stay in his house. Finally government distribute their property among the emigrants two brothers Aziz and Hamid took the property of Sundar but after few years left it and Ghulam Ali and Niaz Ali as emigrant from Arbana Tanda, tehsil Dasua district Hoshiarpur took the property of Nehal and they are still living in house of Nehal.

\section{Changes in Social Networking}

However, after independence, efforts on social reconstruction actually began and has yielded some achievements. During the period (1865-1961), the pattern of village settlement remained consistent on the nucleated pattern. The nucleated village or nucleated pattern is one of the important pattern of settlement. The residential section of the village is located in one unique position, and the agricultural fields are located around the houses in nucleated pattern. The homes are grouped together and built near to one another. In many cases, the walls of the houses are shared by more than one families, and it might be difficult to identify one holding of family from another. Houses are typically packed together based on castes or tribes. The residences were laid out in a Patti-wise arrangement, which was based on genealogy or lineage pattern of settlement looking at the Sajra Nasib of 1891. Patti-wise settlement was completed after division of holding on the bases of Dheri-wise (share wise). In the linage pattern, the working class in the village was left out of this arrangement or settlement. When the size of the population in village increased dispersed pattern after these two patterns of settlement, gained popularity and with the passage of time the old order had come to end. Like minded subtribes (Pattis) settled together and started to intermarriage system and older tradition of six Pattis and three dheries were merged and two Bhainis (Mohallas) are in existence, i.e Lenhdi and chardi patti (east and west). Looking at the settlement in Nauthen houses of five patties are in line and one around other. All Houses of Qaim Patti are in Chardi Bhaini and in same streets, other patti in Chardi Bhaini is Ghulla and two housed of Syed caste. This Bhaini has its own mosque and school and Dairas (social center) and two Lambardars. Lenhdi Bhaini has also two Pattis Hamaon and Saru and has its own mosque, school and Dairas (social centers) and a lambardar. Aaql family was settled at separate Khuh (well) namely Roudu Khuh so they have their 
own social settlement on same line. This was all against the earlier system of the pattis, particular members of the ancestral family had given name to the pattis. In contrast to caste-based settlements, new settlements built during the 2000s do not follow the traditional pattern; many menials' houses are built near Zemindars' homes and vice versa. Houses for people from the same caste and lineage are built in various parts of the village. As a result, people of different castes live in the same area. Houses are built in clusters of 2 to 3 in this layout in the fields. They are either the fathers', brothers', or sons' residences. The majority of inhabitants, whether they lived in the village or at the farmhouse, said it was preferable to remain at the farmhouse since agricultural activities could be better controlled from there. The dwellings, which were largely kaccha before, are now becoming pacca, and some of them are sophisticatedly furnished. However, this is not a complete depiction of the village. There are no plastered walls or paved floors in the so-called pacca dwellings. Alternatively, gates and windows, as well as doors, may be missing. These are the characteristics of residences in general except the few having paved floors, plastered walls and fitted doors and windows properly. Nauthen sought railway station in 1930 and was connected with Hafizabad, wazirabad, Gujranwala, on one side and with Sangla, Faisalabad (Lylpur), Khanewal, Vehari and Multan on the other side and till that name was Nautheh as written on railway record. Railway station raised the position of Nauthen in the surroundings and it became an important village of the area and some local pathways developed to link with different villages. In 1930 a primary school was established that was raised to lower middle class in 1940s, Pandit Sardari Lal was first school teacher and after it Mulvi Ghulam Mustfa from Thatha Asian became school teacher of the said school. In this school in pre partition era Geography, Urdu, Math and Persian were key subjects. School has two class rooms and black boards were in walls. (Mian Khan, 2020) there were number of pathways linking Nauthen with other villages and Eight other wells in the area of Nauthen, most of these has developed as local roads by local government in $21^{\text {st }}$ century. A pathway has been used to connect Nauthen with Lahore Sargodha Road and other. General Muhammad Sawar Khan the governor of Punjab taken special interest to develop single road from Hafizabad to Sukheki that connected Nauthen despite the strong objection of a Tarar from Rasulpur who was a member of Punjab Shura and it completed in 1983-84. Railways station bring higher education in the village and Single macadam bring jobs and urbanization in the lives of people. Their clothing and eating habits were changed. The rural connectionof roads had a significant impact on the village people's lives. The clothing, eating habits, and other attitudes and behaviors of people are changed as a result of the modernization.

\section{Changes in Culture}

Looking at the changes in dress code in Nauthen village Earlier, men used to wear Lakdi (a type of dhoti), kameez, and turban with long chadar on shoulder. Gradually they started wearing shalwar and Kameez with chadar on shoulder and without turban and later on only shalwar Kameez without chadar and turban. Ladies used to wear lakdi (a type of dhoti) and kameez and chadar cover body and head. Gradually Lakdi was replaced with shalwar and chadar to cover only head and shoulders. Looking at the eating habits in Nauthen there was a change eating 
habits, chapattis made of flour of different things like wheat,barley, Maizena, Milo, and beam were used, mostly two times in morning and evening. It is matter of fact the production of crops used for flour were very low and people in village used to make chapatti only one time and eat it two or three times and they cocked salan (Curry) one in a week (Diwana, 2016). After 1980s rice started to include in food items in Nauthen village. Gradually crops production were increased that bring changes in the quantity and quality of food. Yogurt, Lassi, Milk and Makhan were core ingredients of food items and still are being used excluding Makhan that is replaced by cooking oils as milk is being sold at milk dairies. In many houses Lassi (in Nauthen Lassi is called Pung) is replaced with tea. The habit of taking of milk after dinner, taking of Lassi after breakfast and launch were common and but now in many families tea is included in breakfast. There is changed in utensils in which food items were served, Utensils of Magha, Daphal, Koala are replaced with glass for drinking items, Kouli, Thali is replaced with sophisticated pots and plates of china clay and stainless steel and Changair and chaaba are replaced with trays but at larger scale these are still in use. Tauri or Handi are being replaced by cooking pots of stainless steel. Fridge and plastic bottles has replaced completely the use of Ghara or chaati (mud pots) in village.

\section{Changes in Class Structure}

The surname has been an emblem of the social Prestige of the people and to identify the class of the person. It indicated the surname of a specific individual or family. It is by that name that the people are called in the village. Moreover there is $\mathrm{Al}$ that is linked with the caste, living condition, status and occupation, or the features of the people or families or with the place from where the people have migrated. Al in Nauthen village is used to identify the family with its prominent ancestor, place of living for instance Jatt boot (Simple farmer) or Jatt the person or family, adapt to follow the traditional style of living and farming, in Nauthen a family of Muhammad Nawaz Kharal is called Jatt. In family of Miana is example of occupation as families of Mian Manzoor s/o Khuda Bakhash and Mian Abdullah were professional Maulvi leader of the prayers in Mosque, so their Al became Maina. On the bases of Castes in Nauthen there are Randhaira a sub tribe of Kharal, Chadhar, Syed and Kashimiri Butt, Bhagat, Arain, Dhuol, Rehan, Khichi and after it in menials, Mochi (Shoemaker), Maachi (water-carrier), Kubhar (potter), Naee (Barber), Mirasi (minstrel), Bhand (Jokers), Deendaar, Polee (Jullah or weaver), Shaikh, Tarkhan (carpenter), Lohar (ironsmith) Darzi (Tailor) and Dhobi (cleaner and dryer), Mussali (sweepers) and faqir (Begger). Use of $\mathrm{Al}$ or surname is slowly decreasing in the village life as new generation of menials is showing abhorrence towards the use of surname specially associated with them for occupations and adopting new surname or totally avoiding to use surnames or Als. It is matter of fact that whenever someone has asked the menials about the real caste they identified themselves to be a Zamindars or Rajputs. Ibbetson describes caste in terms of occupational restriction (Ibbetson, 1916), or, as Weber does, in respect of status group inflexibility (Weber, 1946). During the collection of data for this new micro 
study on the changes in rural Punjab, it was noted that many menials are using surname of Zamindar or Rajput. It created a big question mark on the reality of their claims, so in this work it is tried to answer it with two theories and one common concept; theory of emigrant origin and theory of real caste. According to theory of emigrant origin, the Menials had been living with some other tribe in any other place and when they left their origin and tribe and reached in new destination to fulfill their living needs and confronted with the a family already having same occupation, they started to introduce themselves with their association of previous tribe. For Instance if a Kumhar family was working for a Khokhar tribe, due to some reasons they migrated and settled in new village in which Kharal tribe was a Zamindar tribe who had already hired a Kumhar family but welcomed the new one. Now the newly arrived family of Kumhar started to identify themselves as Kumhar of Khokhar tribes. It was understood that they were Kumhars, who previously were serving the Khokhar tribe in any other village. Other theory is prior caste theory that is simple as it may be so that a Khokhar family was left with no other occupation except to work as Kumhar they adopted the occupation but remembered their real caste, whom they priory belong. The new $\mathrm{Al}$ or surname being used by the new generations are mostly the same which their elders used to identify in past. Because there are no ritual or commensal restrictions to overcome, changing Quams is relatively simple. In contrast to Hindu India, where such mobility is not conceivable, at least not readily, a change in quom status happens immediately with occupational mobility, even though it is not very common. Similarly, among the Muslim villages of Punjab, the concept of caste contamination has no place. Regardless of quom, all men sit, eat, and smoke together (Ahmad, 1970). Finally the common concept is that menials are changing their castes according to their own choices and avoiding to adopt such castes among them they are living in rural areas as they can be questioned to provide Shajra e Nasab (Pedigree). But in the urban area adopting the new castes is common, as castes in urban areas are less important.

\section{Changes in Entertainment}

During conversations, it was discovered that the entire village comes together to celebrate Eid, Ul Fitar, Eid Ul Adha and Eid Milad Ul Nabi (S.A.W), Shab e Brat, Mihraj Shareef as Muslim festivals and Besakhi, Lodei and Mela of Sufi saints ie. Haji Shah Bukhari and Nawab Shah, were observed as collective festivals of all communities living in Nauthen in pre-partition era. It is matter of fact that throughout human history, entertainment has been an aspect of communal life. The Mela NawabShah a place connected with a Muslim Sufi saint, was a place where an annual Mela (fair) was organized when Sufi Saint Nawab Ali Shah used to some from Main Ali (Kahngah Asrur dogar) with his students. This Mela which included, dancing on Dhol (drum), the singing bands from outside the Nauthen comes to sing the famous stories of Mirza, Sahiban, Heer Ranjha, Sohani Mahiwal and local traditional songs. Along with these activities of night, there were activities of days in Mela like games of Kabbadi, Malkhara, throwing of arrows, tug of war (Sadiq, 2016). In $21^{\text {st }}$ century only Kabbadi is intact and at some places game of volleyball has been introduced.Mela and Eids festivials are on same pattern but Besakhi and Lodei become irrelevant, some kid flocks of Merasi use to come for Lodei but no elder of 
them is involved. After the fixing of date of marriage the night assembly of women in Bride and bridle house were routine for Gawon (songs) in which Giddha and sammi (special kinds of Punjabi dance of women) was must at the end of night show. This tradition is intact but days are reduced. Looking at the main sports in village Nauthen, Lukan Miti or Lukan Michi, Baantey, Pelaan Goli, Ghughu Ghorey, Khido Khonda (local kind of Hockey) Ghoul (wrestling), Guli Danda, Staphu, Lettar Kirla, Wahnju, Peeto graam, chess, Pansa, Gadi Cheera, dog race, bull race, horse dance, tent pigging and many other games have been a regular feature of the rural life. Madari (magicians) Bazigars (acrobats) and Bashaey, (Jaspers) used to come for entraining the people in Nauthen village some with animals like Monkey and the bears. (Rai, 2018)Games are changed Kabbadi, cricket, football, volleyball are grounds games of boys, along with cards, Chor Sepoy, Ludo, tent pigging, horse dance, dog race, dog fight, cock fight. Lukan michi, stapho, and ropejumping are reduced to girls at early age. Merasi were real source of entrainment as they used to play a role of story tellers, stories of two princes, Chan Badshah and Lal Badshah, who were sent in exile, story of extra clever monkey, horrible story of a Daiy (monster), story of Udan Katola (flying chair) were very popular in the village of Nauthen and the episodes of these stories prolonged on years but television and mobile phone has put an end to this source of entertainment (Shabbir, 2017 \& Muzaffar, et. al. 2020).

\section{Change in Wangaar and Seer and SaipSystem}

Since the end of 20th century the Wangaar system (for agricultural labour) had graduallycollapsed. The reimbursement for labor had slowly increased. In Wangaar large number of all Menials, relatives, friends and neighbor came to help the farmers for any kind of help when he called on Wangaar, he served them with best of meal and drinks and nothing else. The exercise of a particular Wangaar working came to an end due the increased in use of machinery in agriculture sector. Another parallel system was system of seer (partnership), in which labor was arranged on the annual basis with a worker who became bound to serve his master for one year on the terms of complete security of food, residence, treatment, dress and all other expenses on festivals, along with fix amount of grain and rice that were paid to him for his family support on bi annual basis. For the self-respect of the worker both the master and worker were called seeri (partners) and Musalli caste was leading or only caste that was identified as suitable caste for seer.Seer system is being replaced with labor on monthly salaries. In same manners there was a saip system, both parties were called saipee in which different kind of Menials were attached to Zamindars for different kind of labor on different rates with some kind of extra obligation on Zamindars with regards to their saipees (Bashir, 2020). The seven kinds of saipees were must for a zamindars as without them he could not have fulfill his needs of social and agricultural life. These seven were; Nai as barber; for his social and personal need, Mochi, as cobbler; to make different kind of tools for agriculture and shoes for him and his family, Machi; to provide the service of Tandoor (cylindrical clay or oven) that was used for bread baking and cooking and 
bringing woods for fire in house of Zamindar along with on social gathering of deaths or weddings was responsible for providing water. Kubhar or Kumhar, was important as he provided services of to measure and shift the crops from fields after crushing and deliver it to different places according to the direction of Zamindar and kneading the dough for guests at death or wedding. Lohar was also important saipee as he was responsible to prepare plough, sickle, iron cutting plate of Kahi, Axe, pruning saw, Tarkhan, was responsible to provide wood handle of all the agricultural tools, Mirasi was responsible for the remembering the pedigree of the Zamindars, entrainment with folk tales in night. In Nauthen, Allah Ditta and Sher Muhammad, Bahwal, sajwal and two other were Nai families, Meera and Mama and Mutal, Sultan and two other were Mirasi, families, Saddad, Mutal, Shana, Ghulam son of Nawab son of sultan son of waryamand five other were Kumhar families, Muhammad and Meera and were Tarkhan families, Wahab and Nawab son of Ameer son of Langar, Murad, Ghana after themSona and Abdullah son of Aalam were Mochi families, Lalu, Muhammad (Muhammada son of Yar Muhammad), Haji and Noora were Machi families, Sharif was lohar family, Mutal, Saddique son of Chakar, Haji Dosat son of Muhammad, Mahala, Khanand five other were Mussali family, Ahmad ali and one other were faqir familie andAll were paid with grain, gur (local sugar) Ghee (local butter), rice, money, dress and different kind of clothes, After them wereGhulam Ali son of Tufial son of Fatehdin, Niaz Ali son of Fatehdin were Dhobi,(clean dryers) families, Yaar Muhammad Darzi (tailor), family, Rehmat Bhand (joke master) family, Sharif Sonar (Gold Smith) family, One Polee, one sheikh family of Rehmat sheikh, One Deendar family of Allah Ditta and one Qassai (Butcher) family of Abdullah Qassai is also living in the village. In the 21stcentury saipee system is taking last breaths in Nauthen as access to the, education and factories has provided the opportunity of job to these menials and they are avoiding the profession of their forefathers. All three systems of Saipee, Seeri and wangaar system were replaced first by contracts and then by day-to-day brokering over the wage to be paid. The kami or menials were at the disposal of Zamindars and they were required to do begar (forced labour) with bi annual payments through crops.Agricultural labor reimbursement was governed by custom and enforced by the Zamindars by the use of penalties ranging from physical violence to arbitrary wage changes, rather than by any market mechanism. The kamin-zamindar relation was very strong as both were interdependent. The houses of the menials were usually placed around the Zamindars who were more caring to them. In Nauthen there are large number of houses of menials are around the Qaim Patti of Randhaira Kharal. Basically there are five Pattis of Randhira Kharal tribe in Nauthen; Qaim, Hamaon, Saru, Aaqal (four brothers from Jalalia)and Ghulla patties, Qaim with 1200 acres out of 4500 acres of total land is largest patti in Nauthen (Liaqat, 2020).After the minor land reforms, few menials got residence plots in the era of Zulfiqar Ali Bhutto in Bhutto colony (currently Jinnah colony) within Nauthen that is land mark of these reforms that bring some kind of changes in the relations of Kami-Zamindar. It can be said that one phase of rural life is ending and it is beginning of new phase of rural life. 


\section{Conclusion}

The data analyzed came from only one village that was to support a micro study of rural life not to prolong it for macro level study and in this case even statistics from one village, such as those supplied here, are insufficient. This study have not divided the different castes of the village into cultivators and noncultivators but provided the details of their occupation just identifying them into two Zamindars and menials. Kharal and Syed are Zamindar classes and impact of technology and modernization on these two classes is seen less in respect of their social identity. Modernization and advancement in agricultural system has effected the menials at large as they are leaving their occupations, residences and adopting new identities of castes. This work is not final work on the changes in villages of Punjab but, it is anticipated that this paper has prompted future research. This work gives some understanding into the economic and political life of the village. This research identify some kind ofdiscrepancy in the knowledge, attitudes and behavior, as well as, most outstandingly, class consciousness in the people living in the village. It should go without saying that this paper is in no way definitive work on the rural life but it could become example of micro study of rural society of Punjab (Pakistan). 


\section{References}

Ahmad, S. (1970). Social Stratification in a Punjabi Village. Contributions to Indian Sociology, 4(1), 105-125. https:// doi.org/10.1177/006996677000400107

Bashir, A. (2020, January 18). Explain seer, saipee and Wangaar system in Nauthen. (I. Khan, Interviewer)

Diwana S. (2016, June 10). How People used to Eat and Dress in Nauthen. (I. Khan, Interviewer)

Doab. (2020, January 17). https://en.wikipedia.org/wiki/Doab

Dosat, K. (2020, February 20). When the first settlement took place in Nauthen. (I.khan, Interviewer).

Fazal, A. A., \& Blochmann, H. (1997). The Ain-E-Akbari (Vol. 2-3). London: Low Price.

Gamsa, M. (2017). Biography and (Global) Microhistory. New Global Studies, 11(3), 231-241. https:/ / doi.org/10.1515/ngs-2017-0024

Geography of District Hafizabad. (2020, August 14). https://hafizabad.dc.lhc.gov.pk/PublicPages/HistoryOfDistrict.aspx

Gupta, A. K. (1991). Emerging pattern of political leadership: A case study of Punjab. New Delhi, India: Mittal Publications.

Haider, K., \& Khan, I. (2017). Impact of Politico-economic Changes on the Resettlement of Kharal Tribe in Punjab. Pakistan Social Sciences Review, 1(II), 177187. doi:10.35484/pssr.2017(1-ii)15

Ibbetson, D. (1916). Panjab Castes. Lahore: Government Printing Press.

Jahangir, N., Rogers, A., \& Beveridge, H. (1968). The Tuzuk-i-Jahangiri; or Memoirs of Jahangir. Translated by Alexander Rogers. Edited by Henry Beveridge. Delhi, Munshiram Manoharlal.

Khan, Z. (2017, May 13). The Nankana Sahib Bridge: Under-construction since 1991. https:// dailytimes.com.pk/11645/the-nankana-sahib-bridge-underconstructionsince-1991/

Liaqat, A. (2020, March 10). How Land was divided in Nauthen. (I. Khan, Interviewer)

List of polling stations for a constituency of election to the national assembly of the NA-87 HAFIZABAD-I. (2018, May 13). https://www.ecp.gov.pk/Documents/generalelections2018/draft polling scheme/Punjab/Hafizabad/Hafizabad NA.pdf 
Mian, K. (2020, April 18). Explain the education in Nauthen. (I. Khan, Interviewer)

Mulla, R. (2020, April 22). explaint the first settlement in Nauthen. (I. Khan, Interviewer)

Muzaffar, M. Yaseen, Z. \& Safdar, S. (2020). Role of Social Media in Political Campaigns in Pakistan: A Case of Study of 2018 Elections, Journal of Political Studies, Volume 27 Issue 2, 141-151

Rai, S. (2018, November 21). What kind of Entertainment was in Nauthen. ( I. Khan, Interviewer)

Rashid, A. (1961). Census report of Distrcit Gujranwala, Karachi: office of Census Commissioner

Safdar, H. (2020, August, 21). Division of settlement. ( I. Khan, Interviewer)

Sadiq, Q. (2016, May 02). Source of entertainment Nauthen. (I. Khan, Interviewer)

Shabbir, H. (2017, April 22). What kind of stories were told by Mirasis in Nauthen. (I. Khan, Interviewer)

Shahbaz, R. (2018, December 30). How People used to Eat and Dress in Nauthen. (I. Khan, Interviewer)

Singh, K. (2009). Changing Social Networks In A Village Of The Punjab. Proceedings of the Indian History Congress,70, 1192-1203. Retrieved March 15, 2020, from http://www.jstor.org/stable/44147763

Sirinivas. D. (30 October, 1950). Social structure in Punjab. New York: the Economic weekly

Soofi, M. (2014, June 13). Punjab Notes: Bar: Forgotten glory of Punjab. Retrieved March 15, 2020, from https://www.dawn.com/news/1112454

The Nankana Sahib Bridge: Under-construction since 1991. (2017, May 13). https:/ / dailytimes.com.pk/11645/the-nankana-sahib-bridge-underconstruction-since-1991/

WB, S. (2020, April 30). Rural population (\% of total population) - Pakistan. https:// data.worldbank.org/indicator/SP.RUR.TOTL.ZS?locations=PK

Weber, M. (1946). From Max Weber: Essays in Sociology, H. Gerth and C.W. Mills, trans. New York: Oxford University Press. 